\title{
PARTNERING ETHICS AND CHEMISTRY IN SECONDARY AND UNIVERSITY STEM EDUCATION VIA AN INNOVATIVELY DESIGNED PERIODIC TABLE OF CHEMICAL ELEMENTS
}

Karina Bramstedt ${ }^{1}$

\begin{abstract}
As declared by the United Nations, 2019 is the International Year of the Periodic Table of Chemical Elements. Accordingly, an innovative new Periodic Table of Chemical Elements and Ethics [PETE] has been developed as an educational tool for secondary and university STEM (Science, Technology, Engineering and Mathematics) education. The tool is designed to be used in a case-based approache that is feasible to both individual and small group learners. Specifically, with the new periodic table, STEM becomes aligned with STSE (Science and Technology on Society and Environment), laying a curricular pathway for integrating discussions of ethics into the teaching of chemistry. Presented is the table, as well as sources for pairable ethics cases, and guidance for teachers to create curriculum which facilitates connections between ethics, chemistry, and society.
\end{abstract}

Keywords chemistry; education; ethics; science/education; educational technology

Ética y química asociadas en la educación secundaria y universitaria STEM, a través de una tabla periódica de elementos químicos de diseńo innovador

Resumen: Según lo declarado por las Naciones Unidas, 2019 es el Año Internacional de la Tabla Periódica de Elementos Químicos. En consecuencia, se ha desarrollado una nueva tabla periódica innovadora de elementos químicos y ética [PETE] como una herramienta educativa para la educación secundaria y universitaria STEM (Ciencia, Tecnología, Ingeniería y Matemáticas). La herramienta está diseñada para usarse en un enfoque basado en casos que sea factible tanto para estudiantes individuales como para grupos pequeños. Específicamente, con la nueva tabla periódica, STEM se alinea con STSE (Ciencia y Tecnología en Sociedad y Medio Ambiente), estableciendo una vía curricular para integrar las discusiones de ética en la enseñanza de la química. Se presenta la tabla, así como las fuentes de casos éticos deseables y orientación para que los maestros creen un plan de estudios que facilite las conexiones entre la ética, la química y la sociedad.

Palabras clave: química; educación; ética; enseñanza de las ciencias; tecnologia Educacional

\section{Associando ética e química na educação stem secundária e universitária via uma tabela periódica de elementos químicos desenvolvida de forma innovadora}

Resumo: Como declarado pelas Naçóes Unidas, 2019 é o Ano Internacional da Tabela Periódica de Elementos Químicos. Portanto, uma inovadora e nova Tabela Periódica de Elementos Químicos e Ética (PETE, sigla em inglês) foi desenvolvida como uma ferramenta educacional para educação STEM (sigla em inglês para Ciência, Tecnologia, Engenharia e Matemática) secundária e universitária. A ferramenta é elaborada para ser usada em uma abordagem baseada em casos, viável tanto para aprendizagem individual como de pequenos grupos. Especificamente, com a nova tabela periódica, STEM se alinha com STSE (sigla em inglês para Ciência e Tecnologia na Sociedade e Ambiente), estabelecendo uma via curricular para integrar discussóes de ética no ensino de química. Apresenta-se a tabela, bem como fontes de casos éticos pareados, e orientação para professores criarem um currículo que facilite conexóes entre ética, química e sociedade.

Palavras chave: química, educação, ética, ciência/educação, tecnologia educacional

\footnotetext{
${ }^{1}$ Luxembourg Agency for Research Integrity (LARI) 6, Luxembourg. Bond University Faculty of Medicine and Health Sciences, Queensland, Australia

Correspondence: txbioethics@yahoo.com
} 


\section{Introduction}

In 2016, Dr Astrid Steele argued in The Journal of Science Teacher Education that there was the "need for a moral component for science education" (1:357). She further stated that an ethical framework would "inform decisions and directions of [STEM] teachers, and teacher educators" (1:359). Concurring, an innovative new design of the Periodic Table of Chemical Elements has been created which facilitates both ethics and chemistry education in secondary schools as well as universities (Figure 1). Specifically, with the new periodic table, STEM content aligns with STSE (Science and Technology on Society and Environment) content, facilitating a curricular pathway to integrate discussions of ethics into the teaching of chemistry. 2019 was declared the International Year of the Periodic Table of Chemical Elements by the United Nations(2), thus the timely creation of this new table for STEM is fitting [See next page].

\section{The Evolution of the Periodic Table of Chemi- cal Elements}

What is known today as the Periodic Table of Chemical Elements had its origination in the mid-1800s by several scientists, including chemist Dmitri Ivanovich Mendeleev and physician Julius Lothar Meyer. Even the contributions and ultimate authorship credit of the table is an ethical issue worthy of debate(3). Due to the table's unique ability to be a visual teaching tool, many variations have been created. These variations are notably different from the original in that they do not aim to also teach chemistry concurrently, but rather the Periodic Table of Chemical Elements becomes only a geometric template with the chemistry content removed. Such examples include the Periodic Table of the Presidents (https://periodicpresidents. com/product/ptotp/), Periodic Table of Figures of Speech (https://visual.ly/community/infographic/ education/periodic-table-figures-speech), and the Periodic Table of Musical Instruments (https://www. kickstarter.com/projects/1913274728/periodic-tableof-musical-instruments).

\section{Meet PETE}

Presented here is a newly designed Periodic Table of Chemical Elements termed the Periodic Table of Chemical Elements and Ethics [PETE.] PETE retains the standard features of the Periodic Table of Chemical Elements(4) (i.e., atomic number, element symbol, element name, atomic mass) while pairing one word relating to ethics or research ethics along with the chemical element. The word pairing aligns to the letters of the element symbol (118 unique pairs). In this way, the geometric layout and scientific content of the Periodic Table of Chemical Elements are retained and visually intact, and the ethics content is added.

Some of the word-element pairs have an immediate ethical connection. For example, potassium (element 19, symbol K) is paired with the ethics word "kind". In this context, students could explore the case of three authors who unkindly plagiarized the work of others who had also researched potassium(5). With regard to element 98 (Californium, symbol Cf), this is paired with the ethics word "confidentiality" and students could explore the National Aeronautics and Space Administration's Aviation Safety Reporting System(6) in the context of Californium's use in the detection of aircraft metal fatigue. Copper (element 29, symbol $\mathrm{Cu}$ ) is paired with the ethics word "culture" and this can be explored in the context of mining harms to indigenous peoples(7). For the word-element pairings that do not [currently] have direct ethical connections, analysis of the pairings in the context of element groups and historical cases is proposed.

Teaching chemistry involves exploring the chemical elements according to their group (vertical column of elements that generally have similar physical and chemical properties), period (horizontal row of elements that have the same number of atomic orbitals), and blocks (table segments relating to electrons). Table 1 collates the ethics words according to element group to facilitate a potential curricular package that can further pair with a chemistry-related ethics case(8) that either the teacher presents for analysis, or that the students search for using the Internet as part of an individual or small group project. Reflective writing could also be added in addition to case discussions(9). Online sources for case studies are presented in Table 2. 


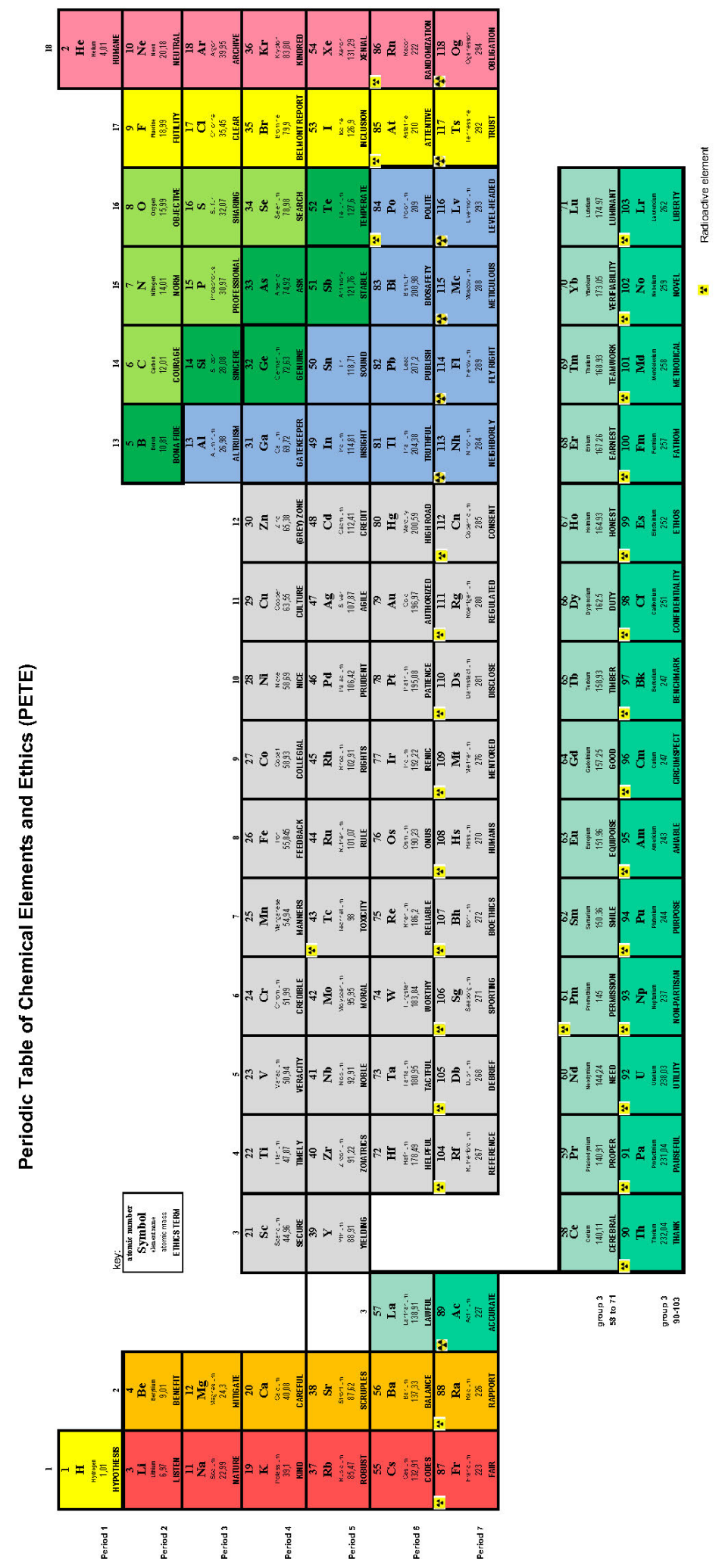


Table 1. Element Groups and the Ethics Terms/ Atomic Number

\begin{tabular}{|c|c|}
\hline Group \# & Ethics Terms \\
\hline 1 & $\begin{array}{l}\text { Hypothesis/1; Listen/3; Nature/11; Kind/19; } \\
\text { Robust/37; Codes/55; Fair/87 }\end{array}$ \\
\hline 2 & $\begin{array}{l}\text { Benefit/4; Mitigate/12; Careful/20; Scru- } \\
\text { ples/38; Balance/56; Rapport/88 }\end{array}$ \\
\hline 3 & $\begin{array}{l}\text { Secure/21; Yielding/39; Lawful/57; Cere- } \\
\text { bral/58; Proper/59; Need/60; Permis- } \\
\text { sion/61; Smile/62; Equipoise/63; Good/64; } \\
\text { Timber/65; Duty/66; Honest/67; Earnest/68; } \\
\text { Teamwork/69; Verifiability/70; Luminant/71; } \\
\text { Accurate/89; Thank/90; Pauseful/91; Util- } \\
\text { ity/92; Non-Partisan/93; Purpose/94; Ami- } \\
\text { able/95; Circumspect/96; Benchmark/97; } \\
\text { Confidentiality/98; Ethos/99; Fathom/100; } \\
\text { Methodical/101; Novel/102; Liberty/103 }\end{array}$ \\
\hline 4 & $\begin{array}{l}\text { Timely/22; Zoiatrics/40; Helpful/72; Refer- } \\
\text { ence/104 }\end{array}$ \\
\hline 5 & $\begin{array}{l}\text { Veracity/23; Noble/41; Tactful/73; De- } \\
\text { brief/105 }\end{array}$ \\
\hline 6 & $\begin{array}{l}\text { Credible/24; Moral/42; Worthy/74; Sport- } \\
\text { ing/106 }\end{array}$ \\
\hline 7 & $\begin{array}{l}\text { Manners/25; Toxicity/43; Reliable/75; Bioeth- } \\
\text { ics/107 }\end{array}$ \\
\hline 8 & Feedback/26; Rule/44; Onus/76; Humans/108 \\
\hline 9 & $\begin{array}{l}\text { Collegial/27; Rights/45; Irenic/77; Men- } \\
\text { tored/109 }\end{array}$ \\
\hline 10 & $\begin{array}{l}\text { Nice/28; Prudent/26; Patience/78; Dis- } \\
\text { close/110 }\end{array}$ \\
\hline 11 & $\begin{array}{l}\text { Culture/29; Agile/47; Authorized/79; Regu- } \\
\text { lated/111 }\end{array}$ \\
\hline 12 & $\begin{array}{l}\text { (Grey) Zone/30; Credit/48; High Road/80; } \\
\text { Consent/112 }\end{array}$ \\
\hline 13 & $\begin{array}{l}\text { Bona Fide/5; Altruism/13; Gatekeeper/31; In- } \\
\text { sight/49; Truthful/81; Neighborly/113 }\end{array}$ \\
\hline 14 & $\begin{array}{l}\text { Courage/6; Sincere/14; } \quad \text { Genuine/32; } \\
\text { Sound/50; Publish/82; Fly Right/114 }\end{array}$ \\
\hline 15 & $\begin{array}{l}\text { Norm/7; Professional/15; Ask/33; Stable/51; } \\
\text { Biosafety/83; Meticulous/115 }\end{array}$ \\
\hline 16 & $\begin{array}{l}\text { Objective/8; Sharing/16; Search/34; Temper- } \\
\text { ate/52; Polite/84; Level-headed/116 }\end{array}$ \\
\hline 17 & $\begin{array}{l}\text { Futility/9; Clear/17; Belmont Report/35; In- } \\
\text { clusion/53; Attentive/85; Trust/117 }\end{array}$ \\
\hline 18 & $\begin{array}{l}\text { Humane/2; Neutral/10; Archive/18; Kin- } \\
\text { dred/36; Xenial/54; Randomization/86; Ob- } \\
\text { ligation/118 }\end{array}$ \\
\hline
\end{tabular}

Table 2. Online Sources for Chemistry-Ethics Case Studies

\begin{tabular}{|c|c|}
\hline Source & Location \\
\hline News stories & $\begin{array}{l}\text { Google search (e.g., search terms } \\
\text { chemist/chemistry, ethics/miscon- } \\
\text { duct, lab/laboratory, poison) }\end{array}$ \\
\hline $\begin{array}{l}\text { Full journal articles dis- } \\
\text { cussing chemistry-ethics } \\
\text { cases }\end{array}$ & $\begin{array}{l}\text { http://www.hyle.org/journal/issues/ } \\
\text { special/ethical-cases.html }\end{array}$ \\
\hline $\begin{array}{l}\text { Fictional chemistry- } \\
\text { ethics cases created by } \\
\text { the American Chemical } \\
\text { Society }\end{array}$ & $\begin{array}{l}\text { https://www.acs.org/content/acs/ } \\
\text { en/about/governance/committees/ } \\
\text { ethics/ethics-case-studies.html }\end{array}$ \\
\hline $\begin{array}{l}\text { Fictional cases in e- } \\
\text { book, chapter } 7 \text {, The } \\
\text { Ethical Chemist }\end{array}$ & $\begin{array}{l}\text { https://global.oup.com/academic/ } \\
\text { product/the-ethical-chemist- } \\
9780190668648 ? \mathrm{cc}=\text { lu\&lang=en\& }\end{array}$ \\
\hline $\begin{array}{l}\text { Catalogue of chemistry- } \\
\text { related retracted journal } \\
\text { articles }\end{array}$ & $\begin{array}{l}\text { https://retractionwatch.com/cat- } \\
\text { egory/by-subject/physical-sciences- } \\
\text { retractions/chemistry-retractions/ }\end{array}$ \\
\hline $\begin{array}{l}\text { Misconduct cases from } \\
\text { the US Office of Re- } \\
\text { search Integrity }\end{array}$ & $\begin{array}{l}\text { https://ori.hhs.gov/content/case- } \\
\text { summary-endo-matthew } \\
\text { https://ori.hhs.gov/content/case- } \\
\text { summary-baughman-brandi-m } \\
\text { https://ori.hhs.gov/content/case- } \\
\text { summary-ramadugu-venkata-sud- } \\
\text { heer-kumar }\end{array}$ \\
\hline $\begin{array}{l}\text { Online chemistry maga- } \\
\text { zine with news content } \\
\text { which includes ethics } \\
\text { cases }\end{array}$ & https://www.chemistryworld.com/ \\
\hline
\end{tabular}


Examples for connecting elements to cases include the following: Strontium (element 39, group 2) could be discussed along with concepts in ethics and nuclear chemistry, specifically, balancing benefits and risks in various settings (medicine, war) and the careful use of mitigation to minimize harm(10). Carbon (element 6, group 14) could be discussed in the context of the ethics of the Pheramor dating app (https://www.pheramor.com/), specifically exploring how the concepts of sincerity, genuineness, soundness and evidenced-based science thread among marketing of "health" and social apps. Silver (element 47, group 11) could be discussed in the context of the ethical complexity of silver nanoparticles, raising concerns about regulations and authorized use (medical use in hospitals vs personal use in socks)(11). Manganese (element 25, group 7) could be discussed in the context of the improperly formulated metal storage vats of the 1919 catastrophic molasses flood, along with the concepts of reliability and professionalism (a synonym for manners) (12). The level of complexity of cases and concepts should be steered by the teacher during curriculum development so as to match the learning environment (secondary vs higher education).

\section{Why Bring Ethics to Chemistry?}

The European Chemical Society established the Working Party on Ethics in Chemistry(13) with objectives that include increasing the awareness of the moral complexity of chemistry activities(14). More specifically, they view the ethical issues as crossing several domains, including good scientific practice, publishing, chemical safety (inside and outside the laboratory), chemical synthesis, education, mentoring, and sustainability (14). Other issues in chemistry include professionalism $(15,16)$ and dual use technologies(11).

The ALL European Academies Permanent Working Group on Science and Ethics argued in their statement on Ethics Education in Science (17), that ethics education should include the ethical aspects of how society interconnects with science. Education about the ethical connections in chemistry has also been promoted by others(18). Yet while the Working Group's focus is the university setting, it seems appropriate to begin these discussions prior to university, where early learners are forming their attitudes, values, and behaviors.

Indeed, the many examples of ethics cases illustrate there are frequent possibilities for ethical dilemmas in the field of chemistry. Memorization of element symbols, atomic numbers and atomic mass, are devoid of the innate contextual connection of chemistry to society, and the ethical matters therein. The use of the PETE in chemistry education is a potential tool for luminating the connection and facilitating discussion and deconstruction. When students make links to real world cases, this can help chemistry seem real and alive, and there is support for this ethics teaching method among chemistry educators(19). For the students who become scientists, "[they] have an obligation to further the conversation about the implications of their work, because they possess more information about the advances that create these ethical questions" (20:59).

A potential limitation of this work is that the ethics words chosen for the PETE table are generally positive or neutral, rather than negative. For example, element 87 (francium, Fr) was assigned the ethics word "FAIR" rather than "FRAUD". Similarly, element 27 (cobalt, Co) was assigned "COLLEGIAL" rather than "CONFLICT OF INTEREST". The PETE table is intentionally created with a positive tone to show the beneficent aspects of ethics; however, through case discussions, the negative aspects of ethical dilemmas will also emerge. For example, when discussing element 82 (lead, Pb, group 14, ethics word "publish") chemistry teachers can include the concept of plagiarism. This notably links to other ethics words in group 14, such as "COURAGE" and "GENUINE". Another potential limitation of this work is that it has not been formally studied as a curriculum tool. It is hoped that the publication of PETE in open-access form will encourage teachers to use it and assess its value with empirical research methods.

\section{Acknowledgements}

The author thanks retired science teacher Kathleen Schenk (Evansville, IN USA) for the open-access Excel template (http://www.sciencegeek.net/tables/ tables.shtml) that was used to build the Periodic Table of Chemical Elements and Ethics. 
Innovatively Designed Periodic Table of Chemical Elements - Karina Bramstedt

\section{References}

1. Steele A. Troubling STEM: Making a case for an ethics/STEM partnership. Journal of Science Teacher Education 2016; 27(4): 357-371.

2. United Nations Educational, Scientific and Cultural Organization. 2019 IYPT International Year of the Periodic Table of Chemical Elements Opening Ceremony. Paris, France. January 2019. Available from: https://en.unesco.org/sites/ default/files/iypt2019-programme-opening_en.pdf Accessed 10 April 2019.

3. Kaji M. Social background of the discovery and the reception of the periodic law of the elements: recognizing the contributions of Dmitri Ivanovich Mendeleev and Julius Lothar Meyer. Annals of the New York Academy of Sciences 2003; 988: 302-306.

4. IUPAC | International Union of Pure and Applied Chemistry. IUPAC Periodic Table of the Elements; 2018. Available from: https://iupac.org/what-we-do/periodic-table-of-elements/\#a9 Accessed 10 April 2019.

5. Yan X, Lv S, Guo R. Retraction: A New Indicator for Potassium Ions at Physiological pH by Using a Macrocyclic Luminescent Metal Complex. Chemistry: A European Journal 2013; 19(19): 5783.

6. National Aeronautics and Space Administration. Aviation Safety Reporting System: Confidentiality and Incentives to Report. Available from: https://asrs.arc.nasa.gov/overview/confidentiality.html Access 1 June 2019.

7. Woollard J. Overcoming the challenges of legacy mines in the Northern Territory. AUSIMM Bulletin 2014; 3: 55-56.

8. Fisher ER, Levinger NE. A directed framework for integrating ethics into chemistry curricula and programs using real and fictional case studies. Journal of Chemical Education 2008; 85(6): 796-801.

9. Coppola BP. Targeting entry points for ethics in chemistry teaching and learning. Journal of Chemical Education 2000; 77(11): 1506-1511.

10. Mast L. Meet Katsuko Saruhashi, a resilient geochemist who detected nuclear fallout in the Pacific; 2019. Available from: https://massivesci.com/articles/katsuko-saruhashi-geochemistry-seawater-japan/ Accessed 10 April 2019.

11. Calderón-Jiménez B, Johnson ME, Montoro Bustos AR, et al. Silver nanoparticles: Technological advances, societal impacts, and metrological challenges. Frontiers in Chemistry 2017; 5: 6 Published 2017 Feb 21. doi:10.3389/ fchem.2017.00006.

12. Rossow MP. The Molasses Flood of 1919 and Other Ethical Failures in Engineering; 2015. Available from: https://pdhonline.com/courses/r151/Molasses\%20flood\%20Study\%20Guide.pdf Accessed 10 April 2019.

13. European Chemical Society. Statutes; 2016. Available from: https://www.euchems.eu/wp-content/uploads/2017/10/ Statutes-WP-on-Ethics.pdf Accessed 10 April 2019.

14. Mehlich J, Moser F, Van Tiggelen B, et al. The ethical and social dimensions of chemistry: reflections, considerations, and clarifications. Chemistry: A European Journal 2017; 23: 1210-1218.

15. Kovac J. Ethics in science: The unique consequences of chemistry. Accountability in Research 2015; 22(6): 312-329.

16. Tragger R. Chemistry graduate student gets seven years for poisoning co-worker. Chemistry World, 13 December 2018. Available from: https://www.chemistryworld.com/news/chemistry-graduate-student-gets-seven-years-for-poisoning-co-worker/3009898.article Accessed 10 April 2019.

17. ALL European Academies Permanent Working Group on Science and Ethics. Ethics Education in Science; 2013. Available from: https://www.allea.org/wp-content/uploads/2015/07/Statement_Ethics_Edu_web_final_2013_10_10. pdf Accessed 10 April 2019.

18. Köster V, Mehlich J. Bringing ethics in chemistry to universities. ChemViews 2018, 4 September. DOI: 10.1002/ chemv.201800076

19. Kovac J. Scientific ethics in chemical education. Journal of Chemical Education 1996; 73(10): 926-928.

20. Wright MB. The role of ethics in stem education: A course proposal (Honor's thesis, Baylor University, Houston, TX, USA); 2017. Available from: https://baylor-ir.tdl.org/handle/2104/9974 Accessed 10 April 2019.

Received: July 5, 2019

Accepted: October 18, 2019 